\title{
Intizar
}

Vol. 24, No. 2, Desember 2018

Website: http://jurnal.radenfatah.ac.id/index.php/intizar

ISSN 1412-1697, e-ISSN 2477-3816

\section{Pola Kerja sama Guru dan Orang Tua dalam Meningkatkan Mutu Pendidikan di MIN 2 Kota Palembang}

\author{
Mgs. Nazarudin ${ }^{1}$ \\ ${ }^{1}$ Universitas Islam Negeri Raden Fatah Palembang, Indonesia, naz_arudin@yahoo.co.id
}

DOI: doi.org/10.19109/intizar.v24i2.3259

\begin{abstract}
Abstrak
Fokus pembahasan dalam penelitian ini adalah kerja sama orang tua dan guru MIN 2 Kota Palembang dalam meningkatkan mutu pendidikan. Permasalahan yang sengaja diangkat dalam penelitian ini adalah: Upaya apa yang dilakukan MIN 2 Kota Palembang dalam membangun kerja sama antara orang tua dan guru? Bagaimana bentuk kerja sama orang tua siswa dan guru dalam meningkatkan mutu pendidikan di MIN 2 Kota Palembang? Sejalan dengan rumusan masalah maka tujuan penelitian ini adalah untuk mengetahui: (1) Upaya sekolah menjalin kerja sama dengan orang tua siswa; (2) Bentuk kerja sama antara sekolah dengan orang tua siswa. Penelitian ini adalah penelitian lapangan dengan menggunakan pendekatan deskriptif kualitatif. Subjek penelitian ini adalah MIN 2 Kota Palembang. Teknik pengumpulan data yang digunakan adalah wawancara dan dokumentasi. Peneliti merupakan instrumen utama dalam melakukan penelitian yang dibantu lembar wawancara dan pedoman dokumentasi. Sumber data atau key information adalah tiga orang (Kepala Madrasah dan 2 orang guru). Data yang terkumpul kemudian dianalisis menggunakan deskriptif kualitatif. Hasil penelitian menunjukkan bahwa: (1) Upaya sekolah menjalin kerja sama dengan orang tua siswa yaitu dengan menciptakan iklim sekolah yang nyaman, melakukan komunikasi awal dengan orang tua, dan menyediakan kesempatan bagi orang tua untuk terlibat dalam kegiatan madrasah; (2) Bentuk kerja sama yang dilakukan antara lain: parenting, komunikasi, volunteer, keterlibatan orang tua pada pembelajaran anak di rumah, dan kolaborasi dengan kelompok masyarakat.
\end{abstract}

Kata Kunci: Kerja sama, Orang Tua siswa, Guru, Mutu Pendidikan

\begin{abstract}
Focus of the discussion in this study was the collaboration of parents and MIN 2 teachers in Palembang City in improving the quality of education. The problems that were deliberately raised in this study were: What efforts were made by MIN 2 Palembang in building cooperation between parents and teachers? What is the form of collaboration between student's parents and teachers in improving the quality of education in MIN 2 Palembang? In line with the formulation of the problem, the purpose of this study is to find out: (1) School efforts to establish cooperation with student's parents; (2) Form of collaboration between school and student's parents. This research is a field research using a qualitative descriptive approach. The subject of this study was school MIN 2 Palembang City. Data collection techniques used were interviews and documentation. The researcher is the main instrument in conducting research assisted by interview sheets and documentation guidelines. Sources of data or key information are three people (Head of MIN 2 Palembang City and 2 teachers). The collected data was then analyzed using qualitative descriptive. The results of the study show that: (1) School efforts to establish cooperation with parents of students are by creating a comfortable school climate, making initial communication with parents, and providing opportunities for parents to be involved in school activities; (2) Forms of cooperation carried out include: parenting, communication, volunteers, parental involvement in children's learning at home, and collaboration with community groups.
\end{abstract}

Keywords: Cooperation, Student's Parents, Teachers, Quality of Education

\section{Pendahuluan}

Salah satu teori perkembangan anak yang sangat terkenal di dalam dunia pendidikan adalah teori ekologi yang dikemukakan oleh Bronfenbrenner (Santrock, 2007, hal. 56). Teori ini memandang 
bahwa perkembangan anak dipengaruhi oleh lima sistem lingkungan yaitu:

a. Mikrosistem adalah lingkungan di mana anak tinggal seperti orang tua, keluarga, teman sebaya, guru, dan sekolah.

b. Mesosistem mencakup hubungan antara mikrosistem seperti orang tua dan guru berinteraksi dalam sistem sekolah, keluarga dengan teman sebaya, dan sekolah dengan tempat ibadah.

c. Ekosistem, yaitu kondisi yang mempengaruhi perkembangan namun anak tidak terlibat secara langsung. Contohnya pengalaman kerja ibu dapat mempengaruhi hubungan dengan anaknya, sehingga mengubah pola interaksi dan komunikasi.

d. Makrosistem mencakup budaya di mana seseorang tinggal seperti adat berperilaku di Indonesia berbeda dengan di negara barat.

e. Kronosistem mencakup berbagai peristiwa hidup yang penting pada individu dan kondisi sosiokultural.

Beranjak dari lima sistem lingkungan di atas dapat dipahami bahwa sesungguhnya perkembangan anak akan dipengaruhi oleh serangkaian interaksi di dalam keluarga, sekolah, masyarakat, sekolah dengan orang tua, sekolah dengan masyarakat, dan masyarakat dengan orang tua. Setiap lapisan lingkungan selalu bersifat dinamis mempengaruhi perkembangan individu. Oleh karena itu perkembangan anak tidak terlepas dari hubungan antara sekolah dan orang tua yang termasuk ke dalam lingkungan mesosistem. Interaksi di antara kedua pihak tersebut akan berpengaruh pada peningkatkan tingkat pencapaian belajar anak. Atas dasar ini maka dapat dikemukakan betapa pentingnya keterlibatan orang tua dalam proses pendidikan anak sebagai pihak yang secara langsung berinteraksi di dalam lingkungan mesosistem. Hal ini akan memberikan pengaruh terhadap perkembangan anak. Oleh karena itu, sekolah perlu merangkul orang tua dalam proses pendidikan.

Terlepas dari teori ekologi di atas, orang tua dalam keluarga memang harus dan merupakan kewajiban untuk memperhatikan anak-anaknya serta mendidiknya (Ahmadi, 2003, hal. 177). Keluarga adalah tempat pertama dan utama bagi pertumbuhan dan perkembangan anak, jika suasana di dalam keluarga itu baik dan menyenangkan maka anak akan tumbuh dengan baik pula, jika tidak, tentu akan terhambat pertumbuhan anak tersebut (Daradjat, 1998, hal. 47).

Dalam kaitannya dengan keluarga sebagai lembaga pendidikan non formal maka tugas utama keluarga bagi pendidikan anak ialah sebagai peletak dasar bagi pendidikan akhlak dan pandangan hidup keagamaan. Sifat dan tabiat anak sebagian besar diambil dari kedua orang tuanya dan dari anggota keluarga yang lain (Hasbullah, 2011, hal. 87).

Tanggung jawab pendidikan yang perlu disadarkan dan dibina oleh kedua orang tua terhadap anak antara lain:

a. Memelihara dan membesarkannya, tanggung jawab ini merupakan dorongan alami untuk dilaksanakan karena si anak memerlukan makan, minum, dan perawatan agar ia dapat hidup secara berkelanjutan.

b. Melindungi dan menjamin kesehatannya, baik secara jasmani dan rohani dari berbagai gangguan penyakit atau bahaya lingkungan yang dapat membahayakan dirinya.

c. Mendidiknya dengan berbagai ilmu pengetahuan dan keterampilan yang berguna bagi kehidupannya kelak sehingga bila ia telah dewasa mampu berdiri sendiri dan membantu orang lain.

d. Membahagiakan anak untuk dunia dan akhirat dengan memberinya pendidikanagama sesuai dengan ketentuan Allah Swt., sebagai tujuan akhir hidup muslim.

Adanya kesadaran akan tanggung jawab mendidik dan membina anak secara kontinu perlu dikembangkan kepada setiap orang tua sehingga pendidikan yang dilakukan tidak lagi berdasarkan kebiasaan yang dilihat dari orang tua.

Guru dan orang tua pada hakekatnya memiliki tujuan yang sama dalam pendidikan anak, yaitu mendidik, membimbing, membina serta memimpin anaknya menjadi orang dewasa serta dapat memperoleh kebahagiaan hidupnya baik di dunia maupun di akhirat kelak. Untuk mewujudkan harapan tersebut, tentunya harus ada kerja sama yang baik antara guru dan orang tua. Kerja sama yang baik antara guru dan orang tua sangat penting karena dua pihak inilah yang setiap hari berhadapan langsung dengan siswa. Jika kerja sama antara guru dan orang tua kurang, maka pendidikan tidak akan berjalan dengan baik bahkan pendidikan yang direncanakan tersebut tidak akan berhasil dengan baik. Kerja sama antara orang tua dan guru akan mendorong siswa untuk senantiasa melaksanakan tugasnya sebagai pelajar, yakni belajar dengan tekun dan bersemangat.

Hubungan kerja sama antara guru dan orang tua murid sangatlah penting. Dengan demikian, maka diperlukan langkah-langkah yang dapat mendukung terlaksananya peningkatan aktivitas belajar dari murid yang dilakukan oleh orang tua, guru dan Intizar, Vol. 24, No. 2, Desember 2018 
keduanya dalam hubungan kerja sama saling membantu dalam meningkatkan aktivitas belajar dari murid tersebut (Yanti \& Rivaie, 2013, hal. 73).

Menurut Eipstein dalam Coleman (2013, hal. 25-27), bentuk kerja sama madrasah dan orang tua dapat dilakukan dalam beberapa bentuk yaitu: parenting, komunikasi, volunteer, keterlibatan orang tua pada pembelajaran anak di rumah, pengambilan keputusan dan kolaborasi dengan kelompok masyarakat. Dengan demikian, bentuk kerja sama antara guru dan orang tua dapat dilakukan mulai dari bentuk yang sederhana, seperti menjalin komunikasi antara guru dengan orang tua. Komunikasi antara keduanya memperkuat proses pembelajaran di madrasah. Langkah tersebut di atas diharapkan membangun persepsi yang sama antara madrasah dan orang tua dalam mendukung proses pembelajaran yang akan diberikan. Pada gilirannya kegiatan belajar anak di madrasah sesuai dengan harapannya sebagai anak, harapan orang tua, dan harapan gurunya. Hubungan yang terjalin baik antara orang tua dan guru/madrasah, akan mengajak orang tua turut memahami lebih awal tentang kehidupan pendidikan anaknya bersama madrasah.

Membangun kerja sama antara guru dan orang tua siswa tidaklah semudah membalikkan telapak tangan. Soemiarti Padmonodewo (2003, hal. 124) menjelaskan bahwa pada kenyataannya tidak mudah menjalin kerja sama kedua belah pihak. Proses pendidikan seperti mendisiplinkan anak, cara berkomunikasi antara anak dan orang dewasa, anak laki-laki dan perempuan, dan budaya seringkali dipandang berbeda antara guru dan orang tua. Jika hal ini terus berkelanjutan, maka kerja sama tidak akan pernah berlangsung. Kesulitan dalam menjalin kerja sama, menurut Slamet Suyanto (2005, hal. 227) dapat terlihat bahwa banyak orang tua ingin membantu guru di madrasah, namun guru kurang memberikan respon, kurang menerima sepenuh hati, dan lebih banyak mengkritik karena mereka merasa lebih ahli dibandingkan orang tua. Oleh karena itu antara orang tua dan guru tidak bisa menjadi tim yang bagus untuk menjalin kemitraan. Padahal kerja sama antara guru dan orang tua perlu dilakukan agar orang tua memperoleh pengetahuan dan pengalaman dari guru dalam hal mendidik anak-anaknya. Sebaliknya, para guru dapat pula memperoleh keterangan-keterangan dari orang tua tentang kehidupan dan karakter siswanya. Jalinan kerja sama keduanya diharapkan dapat meningkatkan hasil belajar siswa.

\section{Metode Penelitian}

Penelitian ini merupakan penelitian kualitatif dengan pendekatan deskriptif. Sumber data dalam penelitian ini adalah kepala sekolah, guru, dan orang tua siswa. Metode pengumpulan data melalui wawancara dan dokumentasi. Adapun proses analisis data yang diperoleh dilapangan dimulai dengan tahapan-tahapan sebagai berikut: 1) Membaca, mempelajari, dan menelaah seluruh data yang diperoleh dari berbagai sumber; 2) Mengadakan reduksi data yang dilakukan dengan jalan membuat abstraksi atau rangkuman yang inti, proses, dan pertanyaan-pertanyaan yang perlu dijaga sehingga tetap berada didalamnya; 3) Menyusun data dalam satuan-satuan; 4) Mengelompokkan satuan-satuan itu dan membuat koding; dan 5) Mengadakan pemeriksaan keabsahan data.

\section{Hasil dan Pembahasan Penelitian Hasil Penelitian}

Sasaran utama dari penelitian ini adalah ingin mengetahui usaha-usaha yang dilakukan MIN 2 Kota Palembang dalam membangun kerja sama antara orang tua dan sekolah dalam pembinaan perilaku keagamaan siswa. Kemudian untuk mendeskripsikan bentuk dari kerja sama itu sendiri. Berdasarkan wawancara dengan key informant (Iskandar, Risnaini dan RA. Mustika) dapat dikemukakan sebagai berikut.

a. Usaha yang dilakukan guna membangun kerja sama orang tua dan sekolah

1) Menciptakan iklim yang nyaman

Manajemen MIN 2 Kota Palembang berusaha merespon setiap orang tua yang datang dengan berbagai maksud dan tujuan, memberikan rasa nyaman baik itu kepada orang tua siswa maupun tamu yang datang untuk kunjungan tertentu, menerapkan 5S (senyum, sapa, salam, sopan, dan santun) sehingga diharapkan orang tua pun menganggap pihak sekolah seperti keluarga. Hubungan antara guru dan orang tua seperti tidak ada jarak dalam berkomunikasi dengan pihak sekolah. Dalam hal ini RA. Mustika menyatakan, "Alhamdulilah. Selama ini setiap ada orang tua yang datang ke sekolah, kita respon dengan baik, kita sambut, kita tanyakan maksud kedatangannya dengan meminta mereka mengisi buku tamu, meminta mereka menunggu di ruang tamu jika yang mereka inginkan tidak dapat segera dipenuhi. Guru dan pegawai diminta untuk 
menerapkan 5S (senyum, salam, sapa, sopan dan santun).

2) Melakukan komunikasi awal dengan orang tua

Manajemen MIN 2 Kota Palembang melakukan komunikasi awal dengan orang tua sudah berlangsung sejaka lama. Artinya bukan baru dilaksanakan pada kepemimpinan kepala MIN 2 Kota Palembang periode ini $(2016$ - 2021) tapi sudah dilaksanakan juga oleh kepala SMA MIN 2 Kota Palembang sebelumnya. Walaupun berbeda kepala berbeda cara namun intinya sama adalah melakukan komunikasi awal dengan orang tua. Menurut Risnaini dapat dikemukakan bahwa, "Selama 3 kepemimpinan kepala sekolah yang dialaminya, semuanya, melakukan komunikasi awal dengan orang tua dan wali siswa, tapi dengan cara yang berbeda. Ada kepada sekolah yang di awal tahun melakukan rapat awal tahun yang dihadiri oleh guru dan seluruh orang tua siswa. Di rapat tersebut kepala sekolah menyampaikan visi, misi, tujuan dan program sekolah secara keseluruhan hingga mengesankan tidak ada yang ditutup-tupi termasuk masalah keuangan. Tapi ada kepala sekolah yang tidak cukup hanya rapat orang tua/wali siswa karena kemudian dilanjutkan dengan wawancara guna mengetahui latar belakang orang tua, minat siswa dan lain sebagainya. wawancara.

Hasil wawancara di atas menegaskan bahwa walaupun berbeda cara yang dilakukan oleh Kepala Sekolah namun intinya sama yaitu pihak sekolah melakukan komunikasi awal dengan orang tua/wali siswa dengan rapat umum saja atau rapat umum dan wawancara.

3) Melibatkan peran orang tua dalam kegiatan madrasah

Kepala MIN 2 Kota Palembang menyediakan kesempatan atau waktu yang memungkinkan bagi orang tua untuk terlibat dan berpartisipasi. Dalam hal ini RA. Mustika menyatakan bahwa, "pihak madrasah menawarkan berbagai kegiatan sekolah kepada orang tua seperti meminta bantuan orang tua untuk menjadi narasumber ketika parenting, mempersilahkan orang tua membentuk kelompok taman baca, menyerahkan kegiatan ekstra kurikuler musik, bina vacalia ke orang tua, meminta bantuan orang tua untuk mengelola kurban, dan memberi kesempatan pada orang tua untuk berkreasi dalam rumah tahfidz".

Tidak semua orang tua mengetahui dimana mereka harus terlibat pada pendidikan anak di sekolah. Oleh karena itu, lanjut Mustika, "sekolah menginformasikan dan menawarkan kepada orang tua di mana mereka bisa ikut ambil bagian dalam proses pendidikan". Keterlibatan orang tua akan memperlancar kegiatan sekolah.

b. Bentuk kegiatan kerja sama antara sekolah dan orang tua

MIN 2 Kota Palembang melakukan kerja sama dengan orang tua dalam berbagai bentuk kegiatan. Dalam hal ini RA. Mustika menyatakan bahwa "Bentuk kegiatan tersebut adalah parenting, komunikasi, volunteer, keterlibatan orang tua pada pembelajaran anak di rumah, dan kolaborasi dengan kelompok masyarakat". Berikut uraian mengenai hal tersebut.

\section{a. Parenting}

Kegiatan parenting pada umumnya dilakukan MIN 2 Kota Palembang dengan mendatangkan narasumber dari luar sekolah. Pihak sekolah mendatangkan narasumber seperti psikiater, dokter, pihak puskesmas, dan ustaz. Materi yang disampaikan berkaitan dengan anak, seperti gizi dan kesehatan anak, pendidikan anak usia sekolah, pendidikan agama, cara melayani anak di rumah, perkembangan anak, permasalahan anak, keterampilan untuk orang tua, pendekatan ke anak, manajemen keuangan bagi orang tua, penanaman akidah akhlak anak, dan bagaimana cara menjadi orang tua sebagaimana diungkapkan oleh Risnaini bahwa "Salah satu kegiatan parenting yang kami lakukan misalnya penyuluhan kesehatan (gizi dan kesehatan anak), manajemen keuangan, pengajian, seminar pembelajaran dan lain-lain".

b. Komunikasi interpersonal

Komunikasi interpersonal yang dimaksud disini adalah komunika antara guru dan orang tua baik dengan menggunakan alat komunikasi elektrik maupun komunikasi cetak (buku penghubung). Komunikasi berguna untuk menerapkan pendidikan yang berkesinambungan. Pihak sekolah dan orang tua berpandangan jika hanya 
salah satu pihak saja yang memberikan pendidikan, maka hasilnya juga tidak akan optimal karena anak menghabiskan lebih banyak waktu di rumah bersama orang tua daripada di sekolah. Ketika anak di sekolah, pembelajaran dilakukan maksimal hanya selama satu jam. Meskipun demikian, tidak menutup kemungkinan sekolah juga dapat memberikan pengaruh yang besar. Oleh karena itu, pendidikan yang didapatkan anak di sekolah lebih baik dilanjutkan atau diterapkan di rumah termasuk pada persoalan akhlak atau perilaku keagamaan seprti berbicara sopan dan bertindak santun, dan lain-lain.

Menurut Iskandar, "salah satu bentuk komunikasi interpersonal (guru dan orang tua) yang dilakukan oleh MIN 2 Kota Palembang adalah dengan buku penghubung. Buku penghubung merupakan salah satu media yang banyak melibatkan orang tua karena apa yang disampaikan oleh guru langsung dapat diketahui oleh orang tua setiap harinya. Orang tua lebih mengetahui perkembangan anak sehingga tidak ada yang terlewatkan dalam setiap tahapannya.

Selain itu, lanjut Iskandar, manajemen MIN 2 Kota Palembang juga menerapkan komunikasi non formal yaitu kunjungan rumah yang dilakukan secara berbeda-beda oleh wali kelas meskipun bersifat insidental. Ada wali kelas yang melakukan kunjungan rumah ketika anak sakit lebih dari seminggu dan ketika ada masalah saja seperti kesalahpahaman antara guru dan orang tua. Ada wali kelas yang menjadwalkan kunjungan rumah pada setiap anak minimal satu kali dalam satu tahun ajaran atau selama berada di sekolah pernah dikunjungi sekali. Ada wali kelas yang menjadwalkan kunjungan rumah pada setiap anak minimal satu kali dalam satu tahun ajaran atau selama berada di sekolah pernah dikunjungi sekali.

c. Volunteer

Sekolah bukan hanya sekedar tempat untuk menitipkan anak, melainkan juga tempat di mana orang tua bisa terlibat dan berpartisipasi lebih jauh lagi dalam pendidikan anak. Oleh karena itu, sekolah selalu melibatkan orang tua dalam berbagai kegiatan baik di bidang pendidikan maupun ekstrakurikuler sebagaimana diungkapkan oleh kepala sekolah berikut ini: "Pendidikan itu bukan saja menjadi tanggung jawab sekolah semata tapi juga menjadi tanggung jawab keluarga (orang tua) dan masyarakat Maka dari itu kami selalu melibatkan orang tua dalam bekerja sama baik dalam bidang pendidikan maupun kegiatan ekstrakurikuler termasuk ekstrakurikulur keagamaan."

Salah satu kegiatan yang banyak melibatkan tenaga orang tua adalah kegiatan volunteer. Kegiatan volunteer di MIN 2 Kota Palembang dilakukan di kelas sebagai pengajar maupun di luar kelas ketika sekolah mengadakan kegiatan. Orang tua siswa MIN 2 Kota Palembang berasal dari berbagai latar belakang yang berbeda. Masing-masing orang tua memiliki berbagai macam keterampilan dan kemampuan sesuai dengan bidangnya. Oleh karena itu orang tua diberdayakan oleh pihak MIN 2 Kota Palembang dalam kegiatan mengajar baik di dalam maupun luar kelas. Menurut Iskandar, kegiatan volunteer yang sudah berlangsung sejak lama adalah "Program baca tulis al-Qur'an, Tahsinul Qiro'ah, Tahfidz Qur'an dan seni bela diri pencak silat". Ke depan MIN 2 Kota Palembang akan memanfaatkan latar belakang mata pencarian orang tua untuk kegiatan ekonomi di MIN 2 Kota Palembang.

\section{Pembahasan Penelitian}

1. Usaha yang dilakukan guna membangun kerja sama orang tua dan sekolah

Orang tua menitipkan anak ke MIN 2 Kota Palembang dengan tujuan agar mereka mendapatkan pendidikan dan berkembang sesuai tahap perkembangannya. Untuk mencapai tujuan tersebut, menurut Santrock, J. W. (2007, hal. 57), "orang tua dan sekolah harus saling bekerja sama. Kedua pihak ini harus ada hubungan secara teratur untuk membicarakan kemajuan anak".

MIN 2 Kota Palembang sudah berupaya membangun hubungan kerja sama dengan orang tua, yang pertama yaitu menciptakan iklim sekolah yang nyaman. Sekolah selalu merespon, memberikan rasa nyaman, menerapkan 5S (senyum, salam, sapa, sopan, dan santun), menyambut, ramah, dan terbuka kepada orang tua dan tamu yang datang ke sekolah. Hal tersebut sesuai dengan pernyataan Beaty (1984, hal. 206) bahwa "suasana baik yang diberikan oleh sekolah dapat menunjukkan jika mereka selalu 
terbuka dan membantu orang tua menemukan cara yang nyaman untuk terlibat pada program pembelajaran anak".

Upaya kedua yaitu melakukan komunikasi awal dengan orang tua. Komunikasi awal di MIN 2 Kota Palembang dilakukan dengan wawancara, pertemuan wali murid baru, dan ada yang keduanya dilakukan di awal tahun. Pada pertemuan tersebut sekolah membicarakan berbagai hal yang utamanya berkaitan dengan anak kemudian dilanjutkan dengan menginformasikan kegiatan sekolah selama satu tahun ke depan beserta aturannya. Hal ini selaras dengan teori Beaty (1984, hal. 206) yang mengatakan bahwa "pada pertemuan awal dengan orang tua, pendekatan paling efektif adalah fokus pada anak, bukan pada program yang akan diselenggarakan di sekolah".

Upaya ketiga yaitu menyediakan kesempatan bagi orang tua untuk terlibat dalam kegiatan pendidikan. Kepala MIN 2 Kota Palembang dengan menawarkan berbagai kegiatan sekolah ke orang tua seperti meminta bantuan orang tua untuk menjadi narasumber ketika parenting, mempersilahkan orang tua membentuk kelompok taman gizi, menyerahkan kegiatan menghias mendekorasi panggung ke orang tua, meminta bantuan orang tua untuk memasak ketika kurban, dan memberi kesempatan pada orang tua untuk berpendapat ketika rapat. Jika sekolah sudah mengupayakannya, maka berbagai bentuk kerja sama akan terlaksana sepanjang kegiatan belajar mengajar berlangsung. Upaya ini dilakukan karena tidak semua orang tua dapat secara otomatis terlibat di sekolah, oleh karena itu pihak sekolah harus mengambil langkah atau inisiatif tersebut. Hal ini sesuai dengan pendapat Coleman (2013, hal. 28) yang menyatakan bahwa "pihak sekolah harus secara aktif melakukan pendekatan kepada orang tua agar mereka dapat terlibat di sekolah karena tidak semua orang tua merasa nyaman mendekati guru untuk mengajukan pertanyaan atau menawarkan bantuan".

2. Bentuk Kegiatan Kerja sama Sekolah dan Orang Tua

Epstein dalam Coleman (2013) menjelaskan bahwa ada enam bentuk kerja sama sekolah dengan orang tua yaitu parenting, komunikasi, volunteer, keterlibatan orang tua pada pembelajaran anak di rumah, pengambilan keputusan, dan kolaborasi dengan kelompok masyarakat. Dari hasil penelitian, ada empat bentuk kerja sama dengan orang tua dari keenam tipe tersebut di MIN 2 Kota Palembang.

Bentuk kerja sama pertama yaitu sekolah mendatangkan narasumber dari luar sekolah seperti psikiater, dokter, pihak puskesmas, dan ustaz untuk menyampaikan materi kepada orang tua. Kegiatan ini termasuk dalam kategori bentuk kerja sama parenting. Materi yang disampaikan dalam acara tersebut berkaitan dengan anak, seperti spiritual building, majlis dzikir, fungsi agama pada anak usia sekolah, cara melayani anak di rumah, perkembangan anak, permasalahan anak, keterampilan untuk orang tua, pendekatan ke anak, manajemen keuangan bagi orang tua, penanaman akidah akhlak anak, dan bagaimana cara menjadi orang tua.

Hal ini selaras dengan Morrison (2012) yang menjelaskan bahwa "cara untuk melakukan pengasuhan dan pendidikan bagi anak, program pelatihan bagi orang tua untuk menjadi pendamping kelas anak, dan pendukung aktivitas belajar merupakan beberapa bentuk kegiatan parenting". Dengan adanya parenting, pihak sekolah mengharapkan agar orang tua menyadari kemampuan anaknya, tidak banyak menuntut terutama pada anak yang mau ke sekolah yang lebih tinggi. Orang tua diharapkan paham dengan perkembangan anak sendiri karena masing-masing anak berbeda. Hal ini sesuai dengan Coleman (2013, hal. 74) yang menyatakan bahwa salah satu manfaat bagi orang tua dengan adanya kerja sama dengan pihak sekolah adalah memberikan informasi pada orang tua tentang perkembangan anak selama di kelas yang berguna bagi orang tua untuk memberikan tindak lanjut ketika di rumah.

Bentuk kerja sama kedua yaitu melakukan komunikasi dengan orang tua. Soemiarti Patmonodewo (2003) menjelaskan bahwa ada dua teknik komunikasi antara sekolah dan orang tua yaitu teknik komunikasi tidak resmi (nonformal) dan teknik komunikasi resmi (formal). Di MIN 2 Kota Palembang, komunikasi jenis formal dilakukan melalui surat, buku penghubung, rapor, dan pertemuan wali. Komunikasi nonformal dilakukan melalui kunjungan rumah, sms/telepon, grup whatsapp, dan ketika menjemput atau mengantar.

Komunikasi berguna untuk menerapkan pendidikan yang berkesinambungan. Pihak sekolah dan orang tua berpandangan jika hanya salah satu pihak saja yang memberikan pendidikan, maka hasilnya juga tidak akan optimal karena pembelajaran dilakukan maksimal hanya selama satu jam. Hal ini senada dengan pendapat Slamet Suyanto (2005, hal. 226) yang menjelaskan bahwa waktu yang dihabiskan anak di sekolah jauh lebih sedikit dibanding waktu anak di rumah. Oleh karena itu apa yang dipelajari di sekolah hendaknya diteruskan di rumah sehingga hasilnya lebih baik.

Bentuk kerja sama ketiga yaitu volunteer. Orang tua membantu sekolah ketika di kelas sebagai 
Pola Kerjasama Guru dan Orang Tua dalam Meningkatkan Mutu Pendidikan di MIN 2 Kota Palembang

pengajar maupun ketika di luar kelas dalam berbagai kegiatan seperti membantu melaksanakan sosiodrama keagamaan, mencarikan penceramah dan tema yang sesuai dengan anak usia sekolah, menjadi panitia acara sekolah, menghias/mendekor gedung untuk malam ekspo seni dan prestasi, mengurusi konsumsi, among tamu di pentas seni, merias anak, memasak ketika kurban, mengantar anak latihan untuk persiapan lomba, menjadi pengurus komite, dan menjadi panitia acara sekolah. Kegiatan kerja sama ini termasuk dalam bentuk volunteer. Dengan adanya bantuan tenaga dari orang tua, guru mengungkapkan bahwa tugas mereka menjadi lebih ringan ketika sekolah mengadakan kegiatan dan proses pembangunan sekolah berjalan lancar sesuai dengan rencana. Hal tersebut selaras dengan teori Coleman (2013) yang menyatakan bahwa pekerjaan guru akan menjadi lebih mudah ketika ada keterlibatan dari orang tua untuk mendukung pembelajaran kelas, program, dan kegiatan yang ada di sekolah.

Bentuk kerja sama keempat yaitu orang tua berperan sebagai guru dengan mengajarkan dan membantu anak untuk mengejar ketinggalan pembelajaran di kelas ketika di rumah. Selain itu, orang tua juga melanjutkan pembelajaran anak di rumah, mendampingi anak belajar, mengulang materi sekolah, dan menerapkan apa yang dibiasakan di sekolah melalui buku penghubung sehingga bisa menjadi contoh bagi anak. Hal ini sesuai dengan teori menurut Slamet Suyanto (2005, hal. 226)(2005: 226) yang menyatakan bahwa buku penghubung digunakan untuk memberitahu orang tua apa yang sedang dipelajari anak di sekolah.

\section{Kesimpulan}

Pendidikan merupakan suatu sistem, terdiri dari berbagai komponen yang saling terkait dan berpengaruh secara timbal balik. Oleh Karen itu, keberhasil atau kegagalan proses pendidikan tidak dapat dibebankan hanya pada salah satu komponen saja misalnya guru atau sekolah/madrasah. Penting adanya kerja sama antara guru dan orang tua.

MIN 2 Kota Palembang telah melakukan usahausaha yang berhubungan dengan kerja sama antara orang tua dan guru/sekolah yaitu dengan menciptakan iklim sekolah yang nyaman, melakukan komunikasi awal dengan orang tua, dan menyediakan kesempatan bagi orang tua untuk terlibat di dalam banyak kegiatan di madrasah. Kemudian, bentuk kerja sama guru/sekolah dengan orang tua siswa diantaranya adalah: parenting, komunikasi, volunteer, dan keterlibatan orang tua pada pembelajaran anak di rumah.

\section{Daftar Pustaka}

Ahmadi, A. (2003). Psikologi Beajar. Jakarta: Rineka Cipta.

Beaty, J. J. (1984). No Title Skills for Preschool Teachers. Columbus: Charles E Merrill Publishing Company.

Coleman, M. (2013). Empowering Family-Teacher Partnership Building Connection within Diverse Communities. Los Angeles: Sage publications.

Daradjat, Z. (1998). Kesehatan Jiwa dalam Islam. Jakarta: Pertja.

Hasbullah. (2011). Dasar-Dasar Imu Pendidikan. Jakarta: Raja Grafindo Persada.

Morrison, G. S. (2012). Dasar-dasar Pendidikan Anak Usia Dini (Fundamentals of Early Childhood Education). (A. Widiastuti, Penerj.). Jakarta: Indeks.

Padmonodewo, S. (2003). Pendidikan Anak Pramadrasah. Jakarta: Rineka Cipta.

Santrock, J. W. (2007). Child Development. (M. Rachmawati \& A. Kuswanti, Penerj.). Jakarta: Erlangga.

Suyanto, S. (2005). Dasar-dasar Pendidikan Anak Usia Dini. Yogyakarta: Hikayat Publishing.

Yanti, M. M., \& Rivaie, W. (2013). Kerja sama Guru Dan Orang Tua Guna Meningkatkan Hasil Belajar Sosiologi Siswa Kelas XI Di SMA Pontianak. Jurnal Pendidikan dan Pembelajaran, 2(6). 